\title{
PENGARUH SOSIAL MEDIA, INFLUENCER DAN CUSTOMER REVIEW TERHADAP KEPUTUSAN PEMBELIAN PRODUK MS GLOW
}

\author{
Falikhaturrohma Dian Narista ${ }^{1}$, Abdurrahman Faris Indriya Himawan ${ }^{2}$ \\ 1,2Program Studi Manajemen, Fakultas Ekonomi dan Bisnis, \\ Universitas Muhammadiyah Gresik, Gresik, Jawa Timur, Indonesia \\ falikhadian2212@gmail.com² ${ }^{1}$ faris@umg.ac.id ${ }^{2}$
}

\begin{abstract}
Background - - In this modern era, cosmetics are no longer a desire for a consumer but have become a daily necessity for humans. Dressing up can make them appear more confident. In Indonesia, the cosmetics business is a promising business opportunity, so it's no wonder that many companies are successful with their cosmetic products. Cosmetics sales are not inferior to other sales in following technological developments.

Objective - To analyze the influence of social media, influencers and customer reviews on customer purchasing decisions for Ms. Glow's cosmetic products.

Design/Methodology/Approach - This research examines the influence of social media, influencers and customer reviews on the decision to purchase Ms Glow product with 95 samples of Ms Glow customers have an Id Card, get data through distributing questionnaires to them and for testing using multiple linear regression analysis with SPSS.

Findings - Social media and influencer variables had an effect on the purchase decision for Ms Glow's products, while the customer reviews had no effect on the consumer purchasing decisions Ms Glow.

Research implications - This research can be used as a reference for viewing and seeking information on social media, influencers and customer reviews of consumer purchasing decisions for Ms Glow products.

Research limitations - In this modern era, customer reviews should be very influential on consumer purchasing decisions because they are done easily, but this research is the opposite with possible answers because they're confident and have customer loyalty to Ms. Glow's products.
\end{abstract}

Keywords: Customer Review, Influencer, Instagram, Purchasing Decision

\begin{abstract}
Abstrak
Latar Belakang - Di era modern seperti saat ini kosmetik tidak lagi menjadi suatu keinginan bagi seorang konsumen melainkan sudah menjadi suatu kebutuhan sehari-hari bagi manusia. Berdandan dapat membuat mereka akan tampil lebih percaya diri. Di Indonesia usaha kosmetik merupakan suatu peluang bisnis yang menjanjikan maka tidak heran apabila banyak perusahaan sukses dengan produk kosmetinya. Penjualan kosmetik tidak kalah dengan penjualan lainnya dalam mengikuti perkembangan teknologi.

Tujuan - Untuk menganalisis pengaruh dari sosial media, influencer dan customer review terhadap keputusan pembelian pelanggan untuk produk kosmetik Ms Glow.

Desain / metodologi / pendekatan - Penelitian kali ini mengkaji pengaruh dari sosial media, influencer dan juga customer review terhadap keputusan pembelian produk Ms Glow dengan 95 sampel dari pelanggan Ms Glow yang sudah memiliki Id Card, mendapatkan data melalui
\end{abstract}

http://dx.doi.org/10.30587/mahasiswamanajemen.v2i01.2369 
penyebaran kuesioner kepada mereka dan untuk pengujiannya menggunakan analisis regresi linear berganda dan membandingkan hasil uji hipotesis dengan bantuan SPSS.

Temuan - Penelitian kali ini memperoleh hasil yang mana variabel sosial media dan influencer berpengaruh terhadap keputusan pembelian produk Ms Glow sedangkan customer review tidak berpengaruh terhadap keputusan pembelian konsumen produk Ms Glow.

Implikasi penelitian - Penelitian kali ini dapat dijadikan referensi untuk melihat dan mencari informasi media sosial, influencer dan customer review terhadap keputusan pembelian konsumen untuk produk Ms Glow.

Batasan penelitian - Di era modern seperti saat ini seharusnya customer review sangat berpengaruh terhadap keputusan pembelian konsumen karena dilakukannya dengan mudah akan tetapi penelitian kali ini sebaliknya dengan kemungkinan jawaban karena yakin dan sudah customer loyalty terhadap produk Ms Glow

Kata kunci : Customer Review, Influencer, Instagram, Keputusan Pembelian

\section{PENDAHULUAN}

Di Era modern seperti saat ini kosmetik ataupun skincare tidak lagi menjadi suatu keinginan bagi masyarakat melainkan sudah menjadi suatu kebutuhan bagi manusia. Mulanya kosmetik ataupun skincare hanya terbuat dari bahan-bahan alami saja seperti kunyit, kemiri, minyak kelapa dan lainnya akan tetapi dengan mengikuti perkembangan teknologi saat ini bahan atau pembuatan dari kosmetik ataupun skincare tidak hanya terbuat dari bahan alami saja melainkan bahan buatan juga sering digunakan oleh perusahaan kosmetik ataupun skincare.

Pengguna dari kosmetik ataupun skincare kini tidak hanya pelanggan wanita saja, akan tetapi laki-laki juga memakainya dan perusahaan juga menyesuaikan perkembangan teknologi untuk kosmetiknya jadi tidak hanya untuk bagian wajah akan tetapi body care juga lagi meningkat penjualannya untuk saat ini. Hal ini yang menjadikan perusahaan kosmetik di Indonesia mengalami keningkatan tiap tahunnya, seperti yang dikatakan oleh Kemetrian Perindustrian Indonesia Industri Kecantikan dan Kosmetik bahwa Indonesia mengalami kenaikan pesat hingga 95\% untuk industri kosmetik kecil ataupun besar.

http://dx.doi.org/10.30587/mahasiswamanajemen.v2i01.2369 


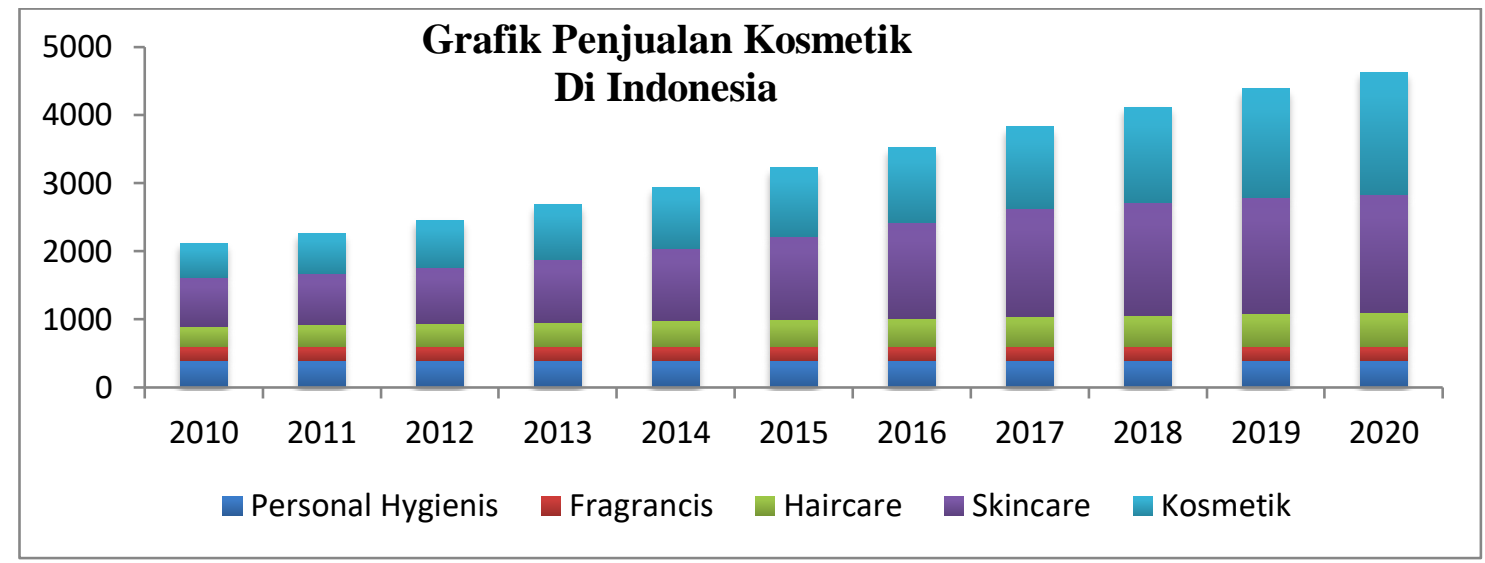

Sumber : Cekindo.com

Grafik 1 : Peningkatan Penjualan Produk Kecantikkan di Indonesia 2020

Grafik 1 menunjukkan bahwa penjualan kosmetik di Indonesia mengalami peningkatan tiap tahunnya mulai dari produk personal hygienis, hair care, skincare, kosmetik tiap tahunnya. Dirjen Industri Kimia Tekstil dan Aneka (IKTA) Achmad Sigit Dwiwahjono mengatakan bahwa Indonesia merupakan salah satu negara pasar potensial untuk usaha kosmetik, sehingga usaha dari kosmetik ini cukup menjanjikan keuntungannya bagi pemilik usaha atau perusahaan.

Banyaknya perusahaan kosmetik menjadikan persaingan jual-beli kosmetik menjadi semakin ketat hal itu membuat persaingan harga juga ketat. Meningkatnya penjualan produk kecantikan di Indonesia tidak terlepas dari adanya merek-merek luar yang ikut berperan namun tidak kalah saingnya produk-produk kecantikan dari dalam yang ikut serta dalam mempengaruhi minat beli seseorang (konsumen). Beberapa contoh merek produk kecantikan lokal yang tidak kalah bagusnya dengan merek produk luar yaitu dari brand Wardah, Mustika Ratu, Purbasari, Viva, Ms Glow dan sebagainya dengan perbandingan jumlah penggemar di akun sosial media masingmasing sebagai berikut :

Tabel 1. Tabel Perbandingan Penggemar Produk Kecantikan Lokal di Instagram 2020

\begin{tabular}{|c|c|c|c|}
\hline No & Brand & Tahun Berdiri & Instagram \\
\hline 1 & Wardah & 1995 & 2,8 juta followers \\
\hline 2 & Purbasari & 1993 & 117 ribu followers \\
\hline 3 & Ms Glow & 2013 & 915 ribu followers \\
\hline 4 & Viva & 1962 & 447 ribu followers \\
\hline 5 & Mustika ratu & 1975 & 153 ribu followers \\
\hline
\end{tabular}

Sumber : Data Olahan Penulis, 2020 
Tabel 1 menunjukkan bahwa produk kecantikan lokal tidak kalah saing dengan produk merek luar dengan perbandingan banyaknya penggemar di akun sosial media Instagram. Mulai dari merek Wardah yang berdiri sejak tahun 1995, kini memiliki jumlah penggemar sebanyak 2,8 juta. Purbasari yang beridiri pada tahun 1993 kini memiliki jumlah penggemar sebanyak 117 ribu penggemar. Ms Glow yang berdiri pada tahun 2013 memiliki jumlah penggemar sebanyak 915 ribu penggemar. Viva yang berdiri pada tahun 1962 memiliki jumlah penggemar sebanyak 447 ribu dan merek mustika ratu yang berdiri pada tahun 1975 memiliki jumlah penggemar sebanyak 153 ribu penggemar.

Ms Glow merupakan merek kosmetik lokal yang bisa dikatakan baru berdiri akan tetapi memiliki jumlah penggemar yang banyak. Ms Glow didirikan oleh Shandy Purnamasari dan Maharani Kemala. Mulanya Ms Glow berproduksi di kota Malang namun kini berdiri dan berkembang di Jakarta. Ms Glow tidak hanya menyediakan bermacam-macam skincare atau kosmetik saja, akan tetapi body care, hair care juga ada. Skincare dari Ms Glow terdiri dari toner, facial wash, day and night cream, foundation, balm juice dan juga serum. Kosmetik dari Ms Glow terdiri dari bedak tabur, lipstick, lipbalm dan untuk body care terdiri dari lotion, serum, body treetment dan minuman penggemuk dan pengurus tubuh. Seorang konsumen membeli dan menggunakan suatu produk kecantikan terdiri dari beberapa faktor pendorong, seperti adanya dorongan dari keluarga, adanya influencer marketing dan juga hasil dari reviews orang lain.

Di Era modern seperti saat ini membeli dan menggunakan suatu propduk kecantikan sangat membantu konsumen dalam memutuskan suatu pembelian, hanya dengan dilakukan secara praktis, mudah, bisa dilakukan dimana saja tanpa membuat konsumen merasa ribet, pergi ke store dan berantri panjang untuk membeli dan melihat suatu produk. Sosial media menjadi salah satu media internet yang dapat membantu seorang konsumen dalam mencari berbagai macam sumber masukan baginya sebelum membeli suatu produk terutama produk kecantikan.

Menurut Kotler dan Keller (2016:642) sosial media merupakan alat atau cara yang sering dilakukan oleh seseorang untuk membagikan informasi yang bisa berupa teks, gambar dan juga vidio dengan tujuan membagikan kepada orang lain yang melihatnya. Mulanya sosial media ada hanya untuk berkomunikasi jarak jauh akan tetapi mengikuti berkembangan jaman dan teknologi menjadikan sosial media sebagai alat untuk 
komunikasi dan penjualan bagi perusahaan. Salah satu contoh dari sosial media yaitu instagram.

Instagram merupakan salah satu aplikasi sosial media tak terbatas yang didirikan oleh Kevin Sistrom dan juga Mike Krigger. Instagram membuat penggunanya mengerti dan mengetahui banyak hal mulai dari adanya selebgram, IG TV, followers, following dan sebagainya, banyaknya pengguna akun sosial media instgram membuat pemilik usaha ataupun perusahaan menginovasi strategi pemasarannya melalui sosial media atau berbasis online. Menjualkan produk online tidak terlepas dari adanya iklan online, bisa dengan iklan beranda dan juga melalui selebgram ataupun influencer.

Influencer menurut Brown dan Fiorella (2013:195) merupakan seseorang yang mempromosikan suatu produk tanpa harus orang yang menggunakan produk tersebut, jadi influencer itu merupakan seseorang yang terpilih atau dipilih perusahaan untuk mempromosikan produknya melalui media internet (online) tanpa melihat orang tersebut menggunakannya atau tidak. Kategori dalam influencer yang sering diperhatikan oleh pelanggan lain yaitu kejujuran dari influencen, kehandalan dalam berucap dan juga daya tarik dalam mempengaruhi orang lain yang melihatnya. Selain influencer yang mempengaruhi konsumen ketika akan membeli atau membandingkan suatu produk yaitu customer review.

Sumarwan (2004:258) menyatakan bahwa di era modern seperti saat ini pembelian kosmetik tidak terlepas dari pemilihan suatu merek dan pengaruh dari pelanggan lain (customer review). Banyak yang memilih customer review sebagai salah satu sumber sebelum melakukan pembelian suatu produk karena melihat customer review itu sangat mudah. Dilakukan hanya dengan search produk yang akan dibeli dan melihat komentarkomentar pelanggan lain yang telah berpengalaman dan terlebih dahulu membeli dan menggunkaan suatu produk. Berdasarkan latar belakang diatas, penelitin kali ini memutuskan untuk meneliti dengan judul pengaruh dari sosial media, influencer dan juga customer review terhadap keputusan pembelian produk Ms Glow.

\section{TINJAUAN PUSTAKA}

\section{Keputusan Pembelian}

Triono (2012:2) pengambilan keputusan merupakan serangkaian proses mental yang dilakukan oleh seseorang dalam menentukan jalan keluar bagi permasalahan yang dihadapinya saat hendak akan membeli sesuatu. Selanjutnya menurut Kotler \& 
Amstrong (2016:177) keputusan pembelian merupakan bagian dari perilaku konsumen tentang bagaimana individu, kelompok ataupun organisasi memilih, membeli dan memutuskan menggunakan barang ataupun jasa untuk memuaskan dan memenuhi kebutuhannya sendiri. Secara garis besar jadi keputusan pembelian merupakan langkah-langkah atau cara yang dilakukan seseorang sebelum bertindak memutuskan untuk membeli atau menggunakan sesuatu.

\section{Sosial Media}

Solis (2010:21) menyatakan bahwa sosial media secara nyata memberikan dampak meningkatkan keputusan pembelian konsumen, menjadikan penjualan online dan trafik situs web jadi meningkat. Seperti hasil penelitian yang dilakukan oleh Mangold \& Fauld (2009), Kurniasih (2018) dan Putri (2016) yang menyatakan bahwa sosial media memiliki pengaruh positif terhadap keputusan pembelian konsumen.

H1 : Sosial media berpengaruh terhadap keputusan pembelian konsumen

\section{Influencer}

Shimp (2003:460) mengatakan bahwa influencer atau iklan menggunakan jasa artis, selebritis ataupun tokoh pesohor merupakan salah satu konsep pemasaran modern yang terkemuka dalam study empiris dan manajerial yang mana dampaknya yaitu dapat memotivasi perilaku konsumen dalam mengambil keputusan pembelian suatu produk. Seperti hasil penelitian yang dilakukan oleh Sloat (2014) dan Hariyanti \& Wirapraja (2018) yang hasilnya menunjukkan bahwa influencer berpengaruh terhadap keputusan pembelian. Berbeda dengan penelitian yang dilakukan oleh Rangga (2018) yang mana hasil penelitiannya menunjukkan bahwa influencer tidak berpengaruh terhadap keputusan pembelian konsumen.

H2 : Influencer berpengaruh terhadap keputusan pembelian konsumen.

\section{Customer Review}

Sutanto \& Aprianingsih (2016:218) mengatakan bahwa customer review termasuk salah satu bentuk electronic world of Mouth dan dapat dikatakan sebagai media komunikasi pemasaran yang baru (modern) yang dapat mempengaruhi serta memegang peran dalam pengambilan keputusan pembelian seorang konsumen. Seperti hasil penelitian yang dilakukan oleh Chua \& Banarjee (2015), Fadhilah (2018), Febrina(2018) dan 
Kawatak (2019) yang mana hasilnya menunjukkan bahwa customer review berpengaruh terhadap keputusan pembelian konsumen.

H3 : Customer review berpengaruh terhadap keputusan pembelian konsumen.

\section{Kerangka Konseptual}

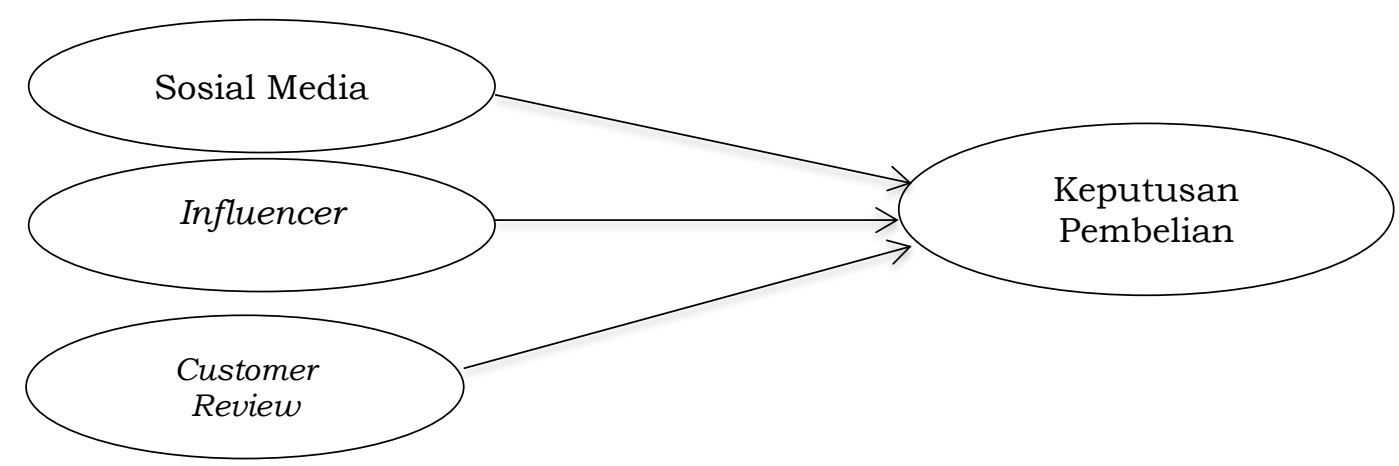

Gambar 1 : Kerangka Konseptual

\section{METODOLOGI PENELITIAN}

\section{Pendekatan dan Lokasi Penelitian}

Penelitian kali ini menggunakan pendekatan penelitian kuantitatif, teknik pengumpulan datanya menggunakan kuesioner. Lokasi dari penelitian kali ini yaitu di Klinik Ms Glow Dee Gresik yang bertempat di Jalan Kapuas No. 03, Randu Agung, Gresik, Jawa Timur, Indonesia.

\section{Populasi dan Sampel}

Populasi dalam penelitian kali ini memilih pelanggan Ms Glow yang memiliki ID Card sebagai subjek penelitian dan Klinik Ms Glow Dee sebagai objek dalam penelitian kali ini. Kemudian untuk sampel peneliti mendapat sumber dari pemilik klinik sebanyak 95 pelanggan yang sudah berID Card dengan menggunakan teknik probalibility sampling atau teknik dengan memberikan peluang kepada semua pelanggan Ms Glow yang berID Card untuk menjadi sempel dalam penelitian kali ini.

\section{Jenis dan Sumber Data}

Jenis data dalam penelitian kali ini yaitu deskriptif kuantitatif yang bersumber pada sumber data primer. Sumber data untuk penelitian kali ini, peneliti mendapatkan sumber data dari pemilik klinik Ms Glow dan untuk data primernya peneliti 
mendapatkan data dari hasil penyebaran kuesioner kepada responden (pelanggan yang berID Card).

\section{Teknik Pengambilan dan Analisis Data}

Teknik pengambilan data pada penelitian kali ini peneliti menggunakan teknik purposive sampling. Metode pengumpulan datanya menggunakan cara penyebaran kuesioner, dan kuesioner tersebut dibagikan oleh peneliti kepada pelanggan Ms Glow yang berID Card dengan cara membagikan link kuesioner dan mendatangi klinik secara langsung. Teknik pengukurannya menggunakan skala likert dengan cara memberi skor 5 untuk jawaban yang sangat setuju, skor 4 untuk jawaban setuju, skor 3 untuk jawaban netral, skor 2 untuk jawaban tidak setuju dan skor 1 untuk jawaban sangat tidak setuju. Analisis data dalam penelitian kali ini menggunakan teknis analisis regresi linear berganda, dimana teknik analisis regresi linear berganda ini digunakan untuk mengetahui dan mengukur seberapa pengaruh antara variabel bebas terhadap variabel terikat (keputusan pembelian) dan menentukan koefisien determinasi sebagai penentu berapakah total presentase variabel bebas dalam mempengaruhi variabel terikat.

\section{HASIL DAN PEMBAHASAN}

\section{Uji Asumsi Klasik}

Tabel 2. Hasil Uji Validitas

\begin{tabular}{|c|c|c|c|c|}
\hline No & Pernyataan & r hitung & $\mathrm{R}$ tabel & Keterangan \\
\hline 1. & \multicolumn{4}{|c|}{ Keputusan Pembelian (Y) } \\
\hline & Y.1 & 0,800 & 0,202 & Valid \\
\hline & Y.2 & 0,751 & 0,202 & Valid \\
\hline & Y.3 & 0,856 & 0,202 & Valid \\
\hline & Y.4 & 0,837 & 0,202 & Valid \\
\hline 2. & \multicolumn{4}{|l|}{ Sosial Media (X1) } \\
\hline & $\mathrm{X} 1.1$ & 0,724 & 0,202 & Valid \\
\hline & $\mathrm{X} 1.2$ & 0,805 & 0,202 & Valid \\
\hline & $\mathrm{X} 1.3$ & 0,747 & 0,202 & Valid \\
\hline 3. & \multicolumn{4}{|l|}{ Influencer (X2) } \\
\hline & $\mathrm{X} 2.2$ & 0,796 & 0,202 & Valid \\
\hline & $\mathrm{X} 2.2$ & 0,855 & 0,202 & Valid \\
\hline & $\mathrm{X} 2.3$ & 0,845 & 0,202 & Valid \\
\hline & $\mathrm{X} 2.4$ & 0,871 & 0,202 & Valid \\
\hline 4. & \multicolumn{4}{|c|}{ Customer Review (X3) } \\
\hline & X3.1 & 0,716 & 0,202 & Valid \\
\hline & $\mathrm{X} 3.2$ & 0,834 & 0,202 & Valid \\
\hline & $\mathrm{X} 3.3$ & 0,782 & 0,202 & Valid \\
\hline
\end{tabular}


Tabel 2 menunjukkan bahwa semua data bersifat valid yang ditunjukkan dari total $r$ hitung $>\mathrm{r}$ tabel.

Tabel 3. Hasil Uji Reliabilitas

\begin{tabular}{|c|l|c|c|c|}
\hline No & \multicolumn{1}{|c|}{ Variabel } & Cronback alpha & Alpha & Keterangan \\
\hline 1. & Keputusan Pembelian & 0,821 & 0,60 & Reliabel \\
\hline 2. & Sosial Media & 0,625 & 0,60 & Reliabel \\
\hline 3. & Influencer & 0,864 & 0,60 & Reliabel \\
\hline 4. & Customer Review & 0,676 & 0,60 & Reliabel \\
\hline
\end{tabular}

Tabel diatas menunjukkan bahwa semua data bersifat reliabel yang ditunjukkan dari total cronchback alpha > alpha.

Tabel 4. Hasil Uji Multikoleniaritas

\begin{tabular}{|c|l|c|c|c|}
\hline No & \multicolumn{1}{|c|}{ Variabel } & TOL & VIF & Keterangan \\
\hline 1 & Sosial Media & 0,695 & 1,440 & Non Multikoleniaritas \\
\hline 2 & Influencer & 0,537 & 1,863 & Non Multikoleniaritas \\
\hline 3 & Customer Review & 0,654 & 1,528 & Non Multikoleniaritas \\
\hline
\end{tabular}

Tabel diatas menunjukkan bahwa data tidak bersifat multikoleniaritas yang dapat dilihat dari nilai hitung tolerance semua > value inflantion factor.

Tabel 5. Hasil Uji Heteroskedastisitas

\begin{tabular}{|c|l|c|c|}
\hline No & \multicolumn{1}{|c|}{ Variabel } & Sig. & Keterangan \\
\hline 1. & Sosial Media (X1) & 0,955 & Non Heteroskedastisitas \\
\hline 2. & Influencer $(\mathrm{X} 2)$ & 0,490 & Non Heteroskedastisitas \\
\hline 3. & Customer Review $(\mathrm{X} 3)$ & 0,120 & Non Heteroskedastisitas \\
\hline
\end{tabular}

Tabel diatas menunjukkan bahwa semua data tidak bersifat heteroskedastisitas yang dapat dilihat dari nilai signifikansi hitung $>0,05$.

Tabel 6. Hasil Uji Normalitas

\begin{tabular}{|lc|c|}
\hline \multicolumn{3}{|c|}{ One-Sample Kolmogrov-Smirnov Test } \\
\hline $\mathrm{N}$ & & \multicolumn{1}{c|}{ Unstandardized Residual } \\
\hline Normal Parameters ${ }^{\mathrm{a}}$ & Mean & 95 \\
\hline \multicolumn{2}{|c|}{ Std. Deviation } & .0000000 \\
\hline Most Extreme Differences & Absolute & 1.78973159 \\
\hline \multicolumn{2}{|c|}{ Positive } & .068 \\
\hline Negative & & .060 \\
\hline Kolmogorov-Smirnov Z & -.068 \\
\hline Asymp. Sig. (2-Tailed) & .661 \\
\hline
\end{tabular}

Tabel diatas menunjukkan bahwa semua data hasil penelitian bersifat normal yang mana dapat dilihat dari nilai signifikansi hitung lebih > dari 0,05. 
Teknik Analisis Data

Analsis Regresi Linear Berganda

Tabel 7. Hasil Uji Regresi Linear Berganda

\begin{tabular}{|c|r|r|r|r|r|}
\hline \multirow{2}{*}{ Model } & \multicolumn{2}{|c|}{$\begin{array}{c}\text { Unstandarized } \\
\text { Coefficients }\end{array}$} & \multicolumn{2}{c|}{$\begin{array}{c}\text { Stanardized } \\
\text { Coefficients }\end{array}$} & \\
\cline { 3 - 7 } & \multicolumn{1}{|c|}{ B } & S.Error & Beta & \multicolumn{1}{c|}{ T } & \multicolumn{1}{c|}{ Sig. } \\
\hline SOSIAL MEDIA & 4.223 & 1.712 & & 2.467 & .016 \\
\hline INFLUENCER & .504 & .143 & .339 & 3.537 & .001 \\
\hline CUSTOMER REVIEW & .333 & .099 & .366 & 3.360 & .001 \\
\hline
\end{tabular}

Tabel diatas menunjukkan bahwa :

1. Sosial media memperoleh nilai $\beta 1$ sebesar 0,504 yang artinya pengaruh sosial media (X1) terhadap keputusan pembelian (Y) sebesar 50,4\%

2. Influencer $\beta 2$ memperoleh nilai sebanyak 0,333 yang artinya pengaruh influencer (X2) terhadap keputusan pembelian $(\mathrm{Y})$ sebasar 33.3\%.

3. Customer Review memperoleh $\beta 3$ sebanyak 0,069 yang artinya pengaruh customer review X3 terhadap keputusan pembelian (Y) sebesar 6,90\%.

Tabel 8. Hasil Uji Determinasi

\begin{tabular}{|l|c|c|c|c|}
\hline Model & R & R Square & $\begin{array}{c}\text { Adjusted R } \\
\text { Square }\end{array}$ & $\begin{array}{c}\text { Std Error of } \\
\text { The Estimate }\end{array}$ \\
\hline 1 & $.649^{a}$ & .421 & .402 & 1.819 \\
\hline
\end{tabular}

Tabel diatas menunjukkan bahwa penelitian kali ini memperoleh total nilai R Square sebesar 0,402 atau 40,2\% yang artinya total pengaruh variabel bebas terhadap keputusan pembelian sebesar $40,2 \%$.

\section{Uji Hipotesis}

Tabel 9. Hasil Uji Hipotesis (Uji t)

\begin{tabular}{|c|c|c|c|c|c|}
\hline \multirow[b]{2}{*}{ Model } & \multicolumn{2}{|c|}{ Unstandarized Coefficients } & \multirow{2}{*}{$\begin{array}{c}\text { Stanardized } \\
\text { Coefficients } \\
\text { Beta }\end{array}$} & \multirow[b]{2}{*}{$\mathrm{T}$} & \multirow[b]{2}{*}{ Sig. } \\
\hline & B & S.Error & & & \\
\hline $\begin{array}{r}1 \\
\text { (Constant) }\end{array}$ & 4.223 & 1.712 & & 2.467 & .016 \\
\hline SOSIAL MEDIA & .504 & .143 & .339 & 3.537 & .001 \\
\hline INFLUENCER & .333 & .099 & .366 & 3.360 & .001 \\
\hline CUSTOMER REVIEW & .069 & .135 & .050 & .509 & .612 \\
\hline
\end{tabular}

Tabel diatas menunjukkan bahwa :

1. Sosial media (X1) berpengaruh terhadap keputusan pembelian (Y) dengan cara melihat total $\mathrm{t}$ hitung 3.537 lebih besar dari $\mathrm{t}$ tabel dan signifikan hitung lebih kecil dari 0,05 . 
2. Influencer $(\mathrm{X} 2)$ berpengaruh terhadap keputusan pembelian $(\mathrm{Y})$ dengan cara melihat total t hitung 3.360 yang lebih besar dari t tabel dan nilai signifikan hitung lebih kecil dari 0,05 .

3. Customer Review (X3) tidak berpengaruh terhadap keputusan pembelian (Y) bisa dilihat dengan melihat total $\mathrm{t}$ hitung hasil penelitian ini sebesar 0,509 yang artinya nilai t lebih kecil dari t tabel dan nilai signifikansi hitung lebih besar dari 0,05.

\section{Interpretasi Hasil Penelitian}

Berdasarkan hasil penelitian dan analisis data dengan bantuan SPSS maka peneliti dapat menginterpretasikan hasil penelitian ini sebagai berikut :

1. Pengaruh sosial media $(\mathrm{X} 1)$ terhadap keputusan pembelian $(\mathrm{Y})$

Hasil penelitian kali ini menunjukkan bahwa variabel sosial media (X1) memiliki pengaruh positif terhadap keputusan pembelian ( $\mathrm{Y})$, maka hasil dalam penelitian kali ini dapat dikatakan sama dan sesuai dengan teori yang dikemukakan oleh Solis (2010:21) yang mengatakan bahwa sosial media secara nyata memberikan dampak meningkatkan keputusan pembelian konsumen, menjadikan penjualan online naik dan trafik situs web juga meningkat. Hal ini juga sesuai dengan hasil penelitian yang lakukan oleh Mangold \& Faulds (2009) dalam penelitiannya yang menunjukkan bahwa sosial media dapat mempengaruhi perilaku konsumen dalam pengambilan keputusan serta pencarian-pencarian informasi secara online.

2. Pengaruh influencer (X2) terhadap keputusan pembelian (Y)

Hasil penelitian kali ini menunjukkan bahwa variabel influencer (X2) berpengaruh positif terhadap keputusan pembelian $(Y)$, maka penelitian ini sesuai dengan teori yang dijelaskan oleh Shimp (2003:460) yang menyatakan bahwa influencer atau iklan menggunakan jasa artis atau selebritis atau bahkan tokoh pesohor merupakan salah satu konsep pemasaran modern yang terkemuka dalam study empiris dan manajerial yang mana dampaknya yaitu dapat memotivasi perilaku konsumen dalam mengambil keputusan pembelian suatu produk. Tidak hanya itu, dengan berpengaruhnya influencer terhadap keputusan pembelian seorang konsumen, hasilnya sama dengan penelitian yang dilakukan oleh Samsinar et al (2002) yang hasilnya menunjukkan bahwa menggunakan jasa influencer ataupun selebgram dalam sebuah iklan modern akan menambah nilai komersil iklan tersebut untuk dibeli bagi yang melihatnya. 
3. Pengaruh customer review (X3) terhadap keputusan pembelian (Y)

Hasil penelitian kali ini menunjukkan bahwa variabel customer review (X3) berpengaruh negatif terhadap keputusan pembelian $(\mathrm{Y})$, maka penelitian ini berbalik dengan teori yang dikemukakan oleh Sutanto \& Aprianingsih (2016:218) bahwa customer review merupakan salah satu bentuk E-WOM dan dapat dikatakan sebagai komunikasi pemasaran yang baru yang dapat mempengaruhi serta memegang peran dalam pengambilan keputusan pembelian seorang konsumen. Berdasarkan hasil analisis diatas pelanggan kurang memperdulikan customer review atau review orang lain karena bagi mereka (pelanggan lain) customer review merupakan aktifitas yang disengaja jadi bukan spontanitas, kemudian customer review itu dilakukan hanya untuk mempopularitaskan diri hal itu yang menjadikan orang-orang kurang setuju akan customer review di era modern seperti saat ini. Tidak hanya itu, pelanggan kurang memperdulikan review pelanggan lain karena mayoritas pelanggan sudah mempercayai akan kualitas produk dari Ms Glow, semua itu menjadikan keputusan pembelian Ms Glow meningkat meskipun konsumen tanpa melihat customer review terlebih dahulu.

\section{KESIMPULAN}

Hasil dalam penelitian kali ini dari judul Pengaruh Sosial Media, Influencer dan Customer Review Terhadap Keputusan Pembelian Produk Ms Glow yaitu :

1. Secara parsial sosial media berpengaruh terhadap keputusan pembelian produk ms glow

2. Secara parsial influencer berpengaruh terhadap keputusan pembelian produk Ms Glow.

3. Secara parsial customer review tidak berpengaruh terhadap keputusan pembelian produk Ms Glow.

4. Hasil penelitian kali ini untuk variabel customer review tidak berpengaruh terhadap keputusan pembelian konsumen untuk produk Ms Glow karena pelanggan sudah yakin akan kualitas dan brand dari Ms Glow jadi, tanpa mereka melihat review terlebih dahulu, mereka sudah yakin dan percaya diri untuk membeli dan menggunakan produk dari Ms Glow ini. 


\section{REKOMENDASI}

Bagi peneliti selanjutnya direkomendasikan untuk menambah variabel bebas misalnya testimoni, selebgram ataupun yang lainnya. Semakin banyak variabel yang digunakan maka semakin mudah untuk mengetahui faktor apa saja yang dapat mempengaruhi konsumen dalam pengambilan keputusan pembelian terutama produk Ms Glow. Perusahaan (Klinik Ms Glow Dee) dapat memaksimalkan sosial media dan influencer karena sangat membantu perusahaan dalam menjualkan produk Ms Glow sehingga akan lebih baik apabila iklan melalui influencer.

\section{DAFTAR PUSTAKA}

Brown, D \& Fiorella, S. 2013. Influencer Marketing. U.S. Printing

Faadhilah, N. (2018). Pengaruh Gaya Hidup Konsumtif dan Beauty Vlogger Sebagai Kelompok Referensi Terhadap Keputusan Pembelian Kosmetik (Studi Kasus Pada Remaja Perempuan Pengguna Kosmetik Korea Di Surabaya). Jurnal Ilmu Manajemen (Jim), 7(1).

Febriana, M \& Yulianto, E. (2018). Pengaruh Online Consumer Review Oleh Beauty Vlogger Terhadap keputusan Pembelian (Survei Pada Mahasiswi Fakultas Ilmu Administrasi Universitas Brawijaya Angkatan 2014/2015 dan 2015/2016 yang membeli dan menggunakan Purbasari Matte Lipstick). Journal Adsmininstrasi Bisnis, 58(1), 1-9

Ferdinand, Augusty. 2006. Metode Penelitian Manajemen. Semarang. Badan Penerbit Unniversitas Diponegoro.

Hariyanti, N, T \& Wirapraja, A. (2018). Pengaruh Influencer Marketing Sebagai Strategi Pemasaran Digital Di Era Modern (Sebuah Studi Literatur). Eksekutif, 15(1),133146.

Hatta, H \& Andreanus, R. (2018). Pengaruh Influencer, Membership Program dan Instagram Ads Terhadap Minat Beli Brand Coach(Studi Kasus Coach, Plaza Senayan) Journal of Enterpreneurship, Management and Industry (JEM), 2(2). 79-89.

Kotler, P \& Keller, L, K. 2016. Marketing Management 15 th edition. United State. Pearson Education.

Kurniasih, R, A. (2018). Pengaruh Sales Promotions Media Instagram Ads Wardah Beauty House Surabaya Terhadap Keputusan Pembelian Konsumen (Doctoral Dissertation, Uin Sunan Ampel Surabaya).

Mangold, W, G \& Faulds, D, J. (2009). Social media: The new hybrid element of the promotions mix. bussinesses horizons, 357-365. 
Priyatno, Dwi. 2012. Cara Kiat Belajar Analisis Data Menggunakan SPSS'20. Yogyakarta. Andi Offaet.

Putri, C, S. (2016) Pengasuh Sosial Media Terhadap Keputusan Pembelian Konsumen Cherie Melalui Minat Beli. Jurnal Manajemen dan Start-up Bisnis, 1(5), 594-603.

Shimp, T. (2003). Periklanan dan Promosi : Aspek Tambahan Komunikasi Pemasaran Terpadu. Alih Bahasa Revyani Syahrial dan Dyah Anikasari. Jakarta. Erlangga.

Solis, B. (2010). The Complete Guide for Brandy adn Bussinesses to Build Cultivate E Measure Success In The New Web New Jersey. Willey

Sugiyono. 2015. Metode Penelitian Kuantitatif, Kualitatif dan R\&D. Bandung. Alfabeta.

Sumarwan, U. 2004. Perilaku Konsumen Teori dan Penerapannya Dalam Pemasaran. Bogor. Ghalia Indonesia.

Sutanto, M, A \& Aprianingsih, A. (2016). The Effect of online Consumer review to ward purchase Intentions : A Study of Premium Cosmetics In Indonesia. Journal of International Conference on Ethics of Bussinesses Economic and social science.

Triono, R, A. (2012). Pengambilan Keputusan Manajerial. Jakarta. Salemba Empat.

V. Wiratna Sujarweni. 2014. SPSS Untuk Penelitian. Yogyakarta. Pustaka Baru Press. 